\title{
Dasatinib-induced pulmonary hypertension in chronic myelogenous leukaemia
}

\author{
Seongseok Yun, ${ }^{1}$ Faiz Anwer, ${ }^{1}$ Nicole D Vincelette ${ }^{2}$
}

${ }^{1}$ Department of Internal Medicine, University of Arizona Medical Center, Tucson, Arizona, USA ${ }^{2}$ College of Medicine, Mayo Clinic, Rochester, Minnesota, USA

\section{Correspondence to} Dr Seongseok Yun, namaska97@gmail.com

Accepted 30 March 2014
CrossMark

To cite: Yun $S$, Anwer $F$ Vincelette ND. BMJ Case Rep Published online:

[please include Day Month Year] doi:10.1136/bcr-2014 204477

\section{DESCRIPTION}

A previously healthy 46-year-old woman presented to the outpatient clinic with chronic general weakness for a month. Physical examination showed splenomegaly and complete blood count showed white cell count $346000 / \mu \mathrm{L}$, haemoglobin $11.2 \mathrm{~g} / \mathrm{dL}$, platelets $336000 / \mu \mathrm{L}$ with a differential of neutrophils $21 \%$, bands $32 \%$, lymphocytes $8 \%$, monocytes $5 \%$, promyelocytes $22 \%$, myelocytes $11 \%$ and blasts $9 \%$. Subsequent bone marrow biopsy showed cellularity of $100 \%$ with marked myeloid hyperplasia and blasts of 21\%. Cytogenetics demonstrated BCR-ABL1 translocation confirming the diagnosis of chronic myelogenous leukaemia (CML). ${ }^{1}$ Imatinib was started as an initial treatment, however the patient developed resistance, therefore second-line tyrosine kinase inhibitor (TKI), dasatinib was started. ${ }^{2}$ Three months after the initiation of dasatinib, the patient developed new exertional dyspnoea associated with chest pain and peripheral oedema. Chest X-ray showed prominent pulmonary arteries (figure 1) and ECG demonstrated new right axis deviation with $T$ wave inversion in precordial leads suggesting right ventricular hypertrophy. Subsequent transthoracic echocardiogram showed right chamber enlargement with elevation of estimated right ventricle systolic pressure (figure 2), although previous echocardiogram showed no evidence of pulmonary arterial hypertension or right heart disease. Chest CT angiogram demonstrated enlargement of the main pulmonary artery without evidence of pulmonary embolism (figure 3). Dasatinib was discontinued and her symptoms improved gradually over the next 6 months, suggesting the diagnosis of

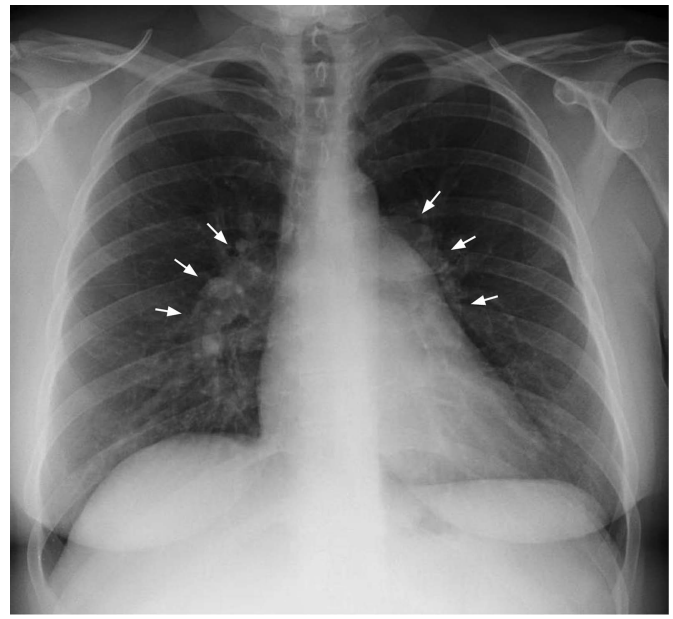

Figure 1 Chest X-ray, posteroanterior view, showing prominent main pulmonary and hilar arteries (arrows) suggesting pulmonary hypertension.

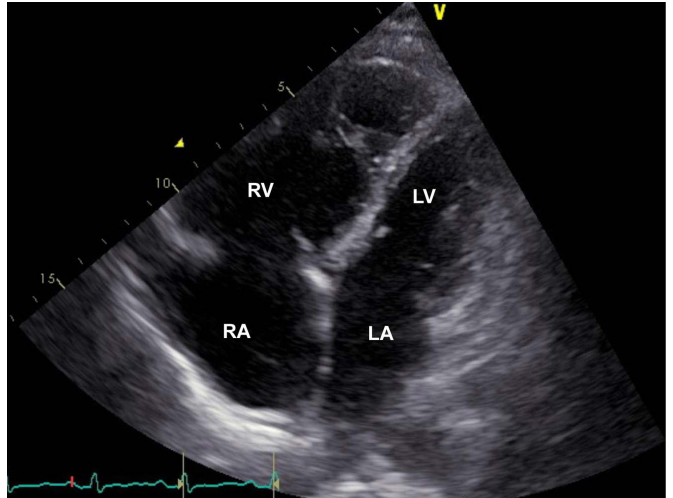

Figure 2 Transthoracic echocardiogram four-chamber view showing flattened septum with elevated right ventricle pressure of $60 \mathrm{~mm} \mathrm{Hg}+$ central venous pressure and right ventricle enlargement. Estimated left atrial pressure is normal (RV right ventricle, LV left ventricle, $R A$, right atrium, LA, left atrium).

dasatinib-induced pulmonary hypertension. Later, nilotinib and bosutinib were tried, however discontinued due to resistance and adverse effects including skin rash and elevated liver enzymes, respectively. Therefore, unrelated allogeneic peripheral blood stem cell transplantation was performed, and the patient is currently in stable disease with BCR-ABL1 0.2\% of total ABL. Pulmonary hypertension is one of the rare complications of dasatinib, a TKI commonly used in patients with CML. ${ }^{3}$ Most of the cases are reversible on cessation of the drug, although some patients develop refractory pulmonary hypertension requiring treatment for that.

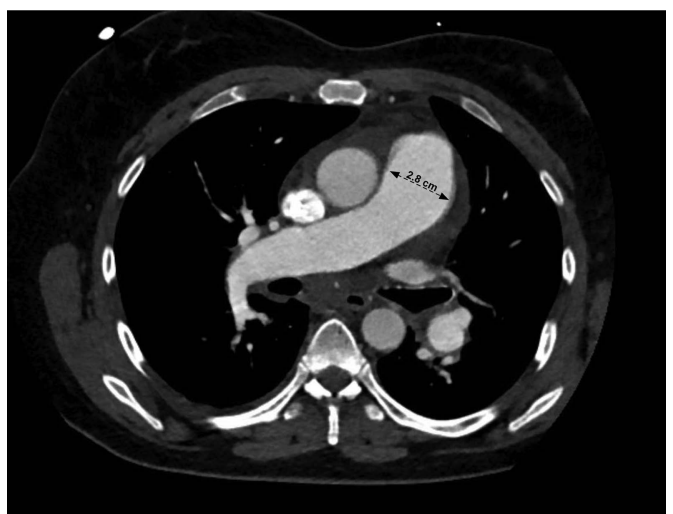

Figure $3 \mathrm{CT}$ of the chest with contrast showing enlargement of the main pulmonary artery measuring $2.8 \mathrm{~cm}$ (double-headed arrow). 


\section{Learning points}

- Pulmonary hypertension is one of the rare complications of dasatinib, and careful monitoring of pulmonary and cardiovascular functions is mandatory in patients with chronic myelogenous leukaemia undergoing dasatinib treatment.

- Most of the cases of dasatinib-induced pulmonary hypertension are reversible after cessation of the drug.
Contributors SY and FA were involved in the care of the patient, collecting data, and all of the authors wrote up the case report. SY reviewed the literature and revised the manuscript.

Competing interests None.

Patient consent Obtained.

Provenance and peer review Not commissioned; externally peer reviewed.

\section{REFERENCES}

1 Sawyers CL. Chronic myeloid leukemia. N Engl J Med 1999;340:1330-40.

2 Baccarani M, Deininger MW, Rosti G, et al. European LeukemiaNet recommendations for the management of chronic myeloid leukemia 2013. Blood 2013;122:872-84.

3 Montani $D$, Bergot $E$, Günther $S$, et al. Pulmonary arterial hypertension in patients treated by dasatinib. Circulation 2012;125:2128-37.

Copyright 2014 BMJ Publishing Group. All rights reserved. For permission to reuse any of this content visit http://group.bmj.com/group/rights-licensing/permissions.

BMJ Case Report Fellows may re-use this article for personal use and teaching without any further permission.

Become a Fellow of BMJ Case Reports today and you can:

- Submit as many cases as you like

- Enjoy fast sympathetic peer review and rapid publication of accepted articles

- Access all the published articles

- Re-use any of the published material for personal use and teaching without further permission

For information on Institutional Fellowships contact consortiasales@bmjgroup.com

Visit casereports.bmj.com for more articles like this and to become a Fellow 